\title{
Impacts of using reformulated and oxygenated fuel blends on the regional air quality of the upper Rhine valley
}

\author{
J.-F. Vinuesa ${ }^{*}$, Ph. Mirabel ${ }^{1}$, and J.-L. Ponche ${ }^{1}$ \\ ${ }^{1}$ Laboratoire de Physico-Chimie de l'Atmosphère, Centre de Géochimie de la Surface, 1 rue Blessig, 67084 Strasbourg \\ Cedex, France \\ *now at: European Commission - DG Joint Research Centre, Institute for Environment and Sustainability, Italy
}

Received: 23 September 2005 - Published in Atmos. Chem. Phys. Discuss.: 23 November 2005

Revised: 15 March 2006 - Accepted: 20 April 2006 - Published: 20 June 2006

\begin{abstract}
The effects of using three alternative gasoline fuel blends on regional air quality of the upper Rhine valley have been investigated. The first of the tested fuels is oxygenated by addition of ethyl-tertio-butyl ether (ETBE), the second is based on a reformulation of its composition and the third on is both oxygenated and reformulated. The upper Rhine valley is a very sensitive region for pollution episodes and several meteorological and air quality studies have already been performed. High temporal and spatial emission inventories are available allowing relevant and realistic modifications of the emission inventories. The calculation period, i.e., 11 May 1998, corresponds to a regional photochemical ozone pollution episode during which ozone concentrations exceeded several times the information threshold of the ozone directive of the European Union ( $180 \mu \mathrm{g} \mathrm{m}^{-3}$ as 1 hourly average). New emission inventories are set up using specific emission factors related to the alternative fuels by varying the fraction of gasoline passenger cars (from 50\% to 100\%) using the three fuel blends. Then air quality modeling simulations are performed using these emission inventories over the upper Rhine valley. The impact of alternative fuels on regional air quality is evaluated by comparing these simulations with the one using a reference emission inventory, e.g., where no modifications of the fuel composition are included. The results are analyzed by focusing on peak levels and daily averaged concentrations. The use of the alternative fuels leads to general reductions of ozone and volatile organic compounds (VOC) and increases of $\mathrm{NO}_{\mathrm{x}}$ levels. We found different behaviors related to the type of the area of concern i.e. rural or urban. The impacts on ozone are enhanced in urban areas where $15 \%$ reduction of the ozone peak and daily averaged concentrations can be reached. This behavior is similar for the $\mathrm{NO}_{\mathrm{x}}$ for which, in addition, an increase of the levels can
\end{abstract}

Correspondence to: J.-L. Ponche

(ponche@illite.u-strasbg.fr) be noted in urban plumes over rural areas. The most important decreases of the total VOC levels are mainly located over rural areas (more than 5\% reduction of the levels except in urban plumes). By comparing these results with those from a local study related to the air quality of Strasbourg, we estimate that the regional contribution to the urban air quality of Strasbourg allows an enhancement of the results by using alternative fuel blends at the regional scale.

\section{Introduction}

More and more major cities and regions, especially in industrialized countries, are subjected to the increase of the occurrence of photochemical pollution episodes. In such regions, one of the main anthropogenic contributions of photochemical precursor compounds is that from road traffic (Derwent et al., 1998, 2003). The use of alternative fuels has been suggested at the end of the eighties in order to improve urban air quality by reducing combustion-related pollution. Indeed, reformulating the fuel (modification of the chemical composition of the fuel e.g. by lowering of the aromatic fraction, and/or addition of oxygenated compounds, as here the ethyltertio-butyl-ether or ETBE) allows the modification of the composition of the emissions (Gaffney and Marley, 2000). Previous studies have shown discrepant results on pollutant emission levels. The addition of ETBE in gasoline fuels leads to a reduction of carbon monoxide emissions (Kivi et al., 1992; Reuter et al., 1992; Noorman, 1993) and VOC emissions (Noorman, 1993). Some authors report an increase of the $\mathrm{NO}_{\mathrm{x}}$ emissions (Reuter et al., 1992; Noorman, 1993) while others show no influence (Kivi et al., 1992; McDonald et al., 1994). Lopez de Rodas and Marduel (1997) measured the emissions for some French cars using two ETBE gasoline fuel blends and a reformulated fuel. They showed that the

Published by Copernicus GmbH on behalf of the European Geosciences Union. 
$\mathrm{CO}$ and VOC emissions are lowered by the addition of ETBE in the gasoline. On the contrary, the use of such fuels leads to an increase of $\mathrm{NO}_{\mathrm{x}}$ emissions. Only the use of the reformulated gasoline fuel blend may simultaneously decrease the $\mathrm{NO}_{\mathrm{x}}$, VOC and $\mathrm{CO}$ emission levels. By using the emission factors from Lopez de Rodas and Marduel (1997), one can study the impact of using reformulated and oxygenated fuel blends on spatial emission inventories. Since the modification of the composition of exhaust pipe emissions is expected to affect the chemical transformations in the atmosphere, we have chosen to quantify and to analyze the effects of these alternative fuels on pollutant concentration fields. We have performed this analysis by building emission scenarios and simulating the air quality for a given representative photochemical pollution episode.

Few studies have addressed the effect of using alternative fuels on air quality and they are mainly focused on the use of methanol-contained fuels (Chock et al., 1994; Kumini et al., 1997, Hsieh et al., 2002, He et al., 2003). Recently, Vinuesa et al. (2003) (referred to as V2003 in the rest of the discussion) studied the effect of using reformulated and oxygenated gasoline fuel blends on the air quality of an urban area. In particular, their work addressed the impacts of these fuels on the emissions of primary and secondary pollutants with respect to the specific European car fleet and emission speciation. They showed that the use of such fuels leads to an increase of NO concentrations and to a significant decrease of the VOC levels while ozone concentration reductions appear to be modest. The purpose of our paper is to extend their work to the regional scale. We intend to relate the effects of using alternative fuels with the type of area, i.e., urban and rural. Moreover, the comparison of the results obtained with the work of V2003 allows us to estimate the contribution of the regional scale transport of air pollutants on urban air quality e.g., at local scale.

The structure of the paper is as follows. In Sect. 2, we present the emission inventories and scenarios. Details of the numerical simulation characteristics and the results of the benchmark simulation are discussed in Sect. 3. In the following section, the impacts of using alternative fuels on regional air quality are evaluated and analyzed. A discussion on the comparison between results obtained at the local or at the regional scales is presented in Sect. 5 followed by conclusions in Sect. 6.

\section{Emission inventories}

The regional domain of investigation is the upper Rhine valley. This domain that regroups regions of three countries (Germany, Switzerland and France) can be considered as a very sensitive area for atmospheric pollution episodes especially photochemical ones during summertime. This is mainly due to the topography and the level of urbanization of this region. The valley is surrounded by mountains on three sides: Vosges, the Black Forest, and Jura on the western, eastern and southern parts respectively. The highest peaks are the Feldberg (1493 m) and the Grand Ballon (1425 m) in the southern parts of respectively the Black Forest and Vosges. The bottom of the valley is very flat and is in the range of 120 to $180 \mathrm{~m}$ from north to south. This configuration have large impact on the dynamics of the low atmosphere and it leads to large periods of weak wind with temperature inversion and even if the topography favors the emergence of local valley and mountains breezes, polluted air masses remain over the valley and are hardly dispersed at regional scale. Even if strong regulations on industrial and car emissions are applied in these three countries, the occurrence of photochemical episodes is still increasing due to this air quality sensitivity. Thus this area has been extensively studied in the past (e.g., Adrian and Fiedler, 1991; REKLIP, 1995, 1999; Schneider et al., 1997; Ponche et al., 2000).

\subsection{INTERREG II emission inventory}

The base case emission inventory has been derived from the yearly inventory performed in the framework of the whole upper Rhine valley INTERREG II program. This air quality management program concerns three different countries within administrative boundaries (Fig. 1): Switzerland (Swiss Cantons of Basel City and Basel Countryside), Germany (State of Baden-Württemberg and part of RheinlandPfalz) and France (Alsace Region). This program included the elaboration of a high space resolution $\left(1 \times 1 \mathrm{~km}^{2}\right)$ emission inventory for the reference year 1998. Several public and private offices participated to identify and quantify the different contributions of this emission database and our Laboratory has participated for the French part. The area under study is $20623 \mathrm{~km}^{2}$ and the density of population is important (6.327 Millions of inhabitants, which is equivalent to about 300 inhab. $/ \mathrm{km}^{2}$ ). The population distributions (and density in inhab. $/ \mathrm{km}^{2}$ ) are $0.454 \mathrm{M}(820), 4.160 \mathrm{M}$ (352) and $1.713 \mathrm{M}$ (210) for Switzerland, Germany and France, respectively. There are several main cities (Karlsruhe, Strasbourg, Freiburg-im-Brisgau, Mulhouse, Basel) but an important part of the inhabitants lives in the countryside in numerous small communities. Moreover, two main highways (total of $811 \mathrm{~km}$ ) bearing a heavy volume of local, regional and international road traffic go across this part of the Rhine valley. The vehicle fleet (registered in the whole area) is $3.7 \mathrm{M}$ including 331230 heavy-duty vehicles.

The approach chosen for most of the sources was the bottom-up methodology presented in Ponche et al. (2000), Vinuesa (2000) and Ponche and Vinuesa (2005). Biogenic and anthropogenic contributions, as well as all the emitted chemical compounds, which can have an impact on the air quality, were considered. Further details about this air quality emission inventory are reported in INTERREG II (2000).

Supplementary data have been collected for the adjacent regions and the same methodology of emission calculation 


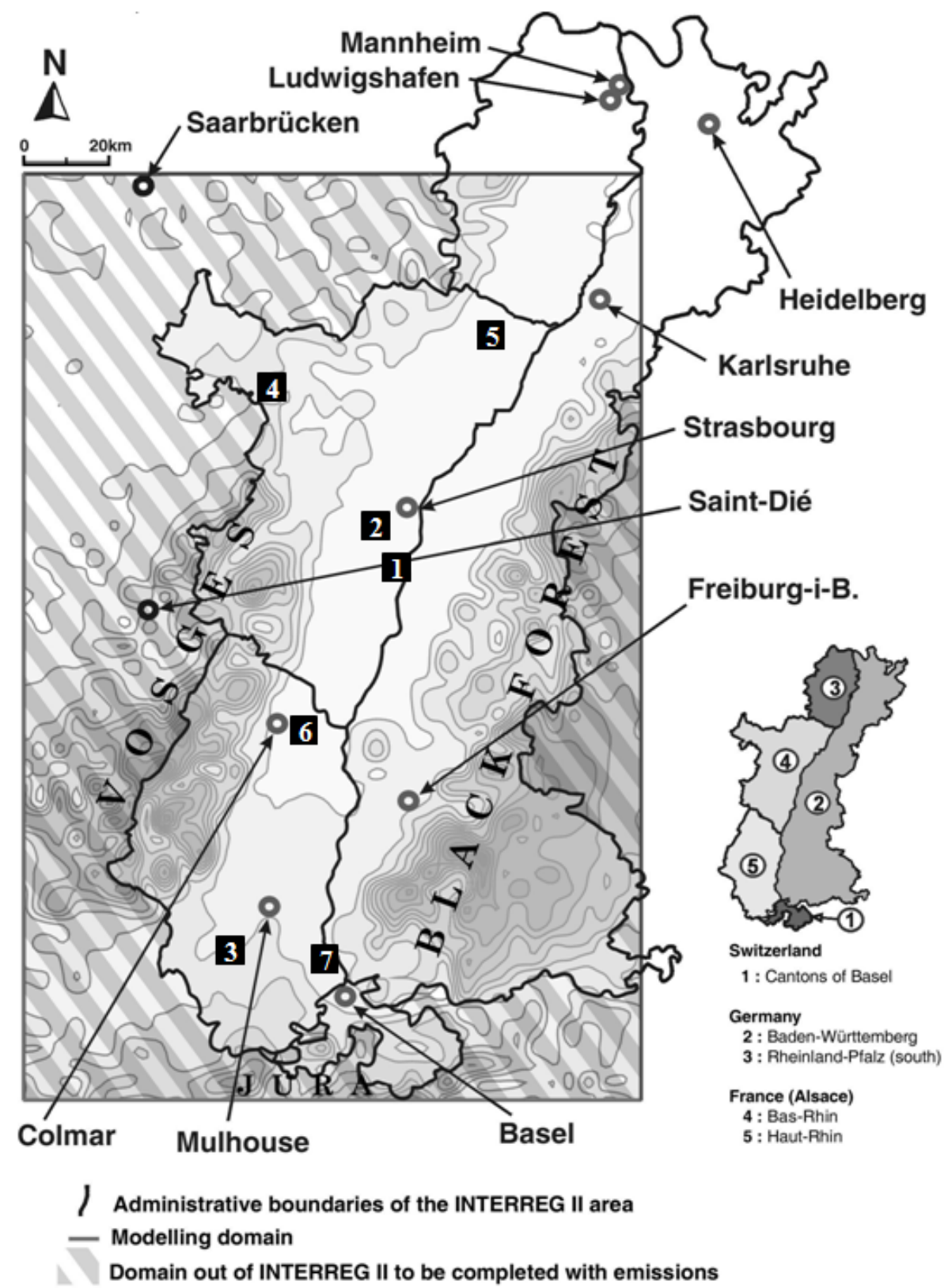

Fig. 1. Extension of the emission inventory and scenario, computational domain, topography of the investigation area and location of the main measuring stations of the Air Quality survey network (1: DRIRE; 2: Strasbourg Ouest; 3: Mulhouse Sud; 4: Vosges du Nord; 5: Nord-Est Alsace; 6: Colmar Est; 7: District des 3 frontières).

has been applied to obtain a investigating domain of $144 \mathrm{~km}$ (East-West) $\times 216 \mathrm{~km}$ (North-South) more suitable for air quality modeling purpose. Then the hourly emission inventories were derived from INTERREG II, by collecting hourly data when available and, if not, by using various time distribution functions related to the different emission source categories. In addition, specific speciation of $\mathrm{NO}_{\mathrm{x}}\left(\mathrm{NO}\right.$ and $\left.\mathrm{NO}_{2}\right)$ and VOCs were used for each category of sources to allow an extensive chemical description of the emissions. This paper focuses on May 11, 1998, to be consistent with the previous study which was done at a local scale (V2003). This day falls in the typical regional photochemical ozone episode of 9-15 May 1998. Low synoptic wind and high temperatures were observed which lead to 28 exceedances of the information threshold of $180 \mu \mathrm{g} \mathrm{m}^{-3}$ in the urban area of Strasbourg. The maximum ozone concentration has been measured at $193 \mu \mathrm{g} \mathrm{m}^{-3}$ on 11 May. During this day, the road traffic has contributed to the total regional daily emissions of 

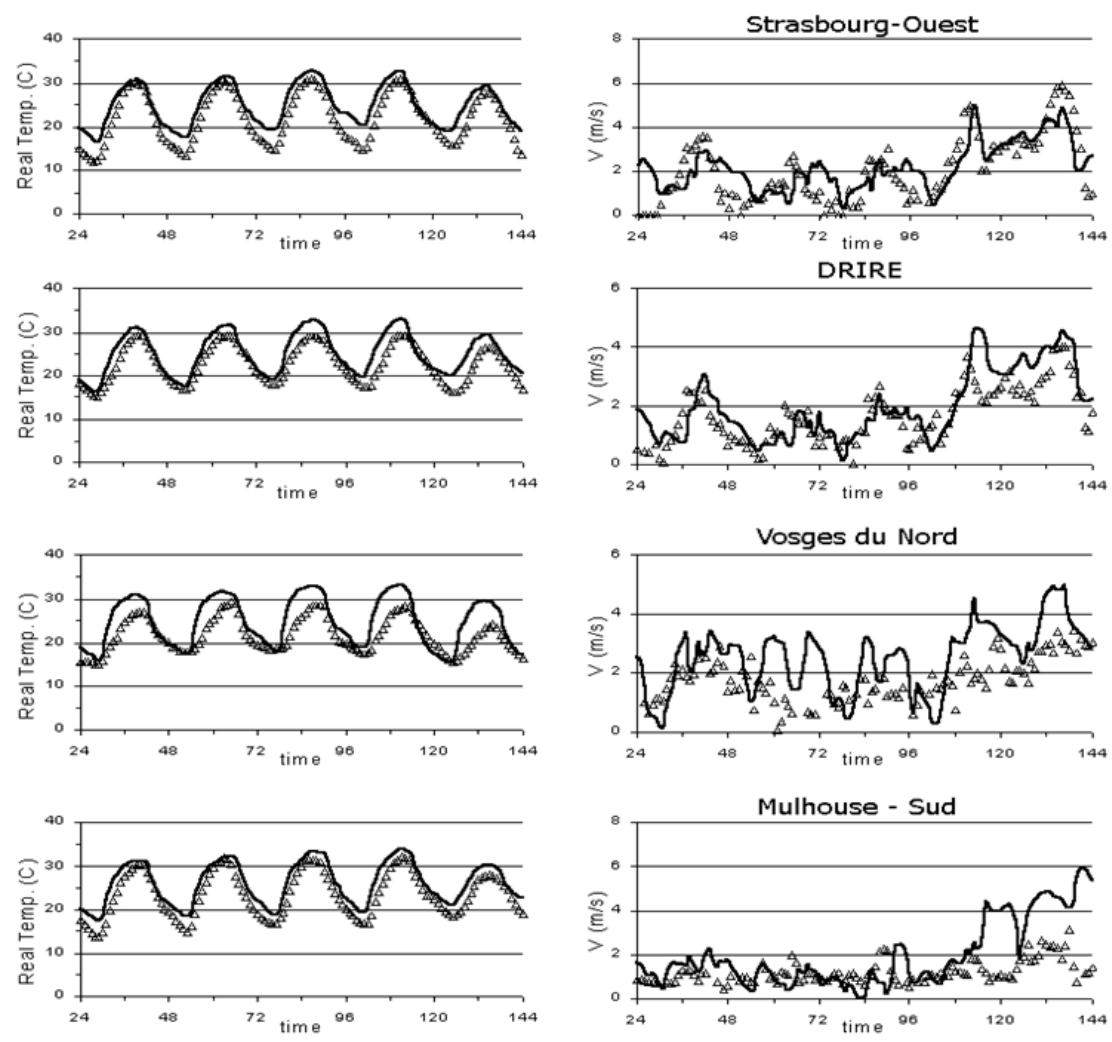
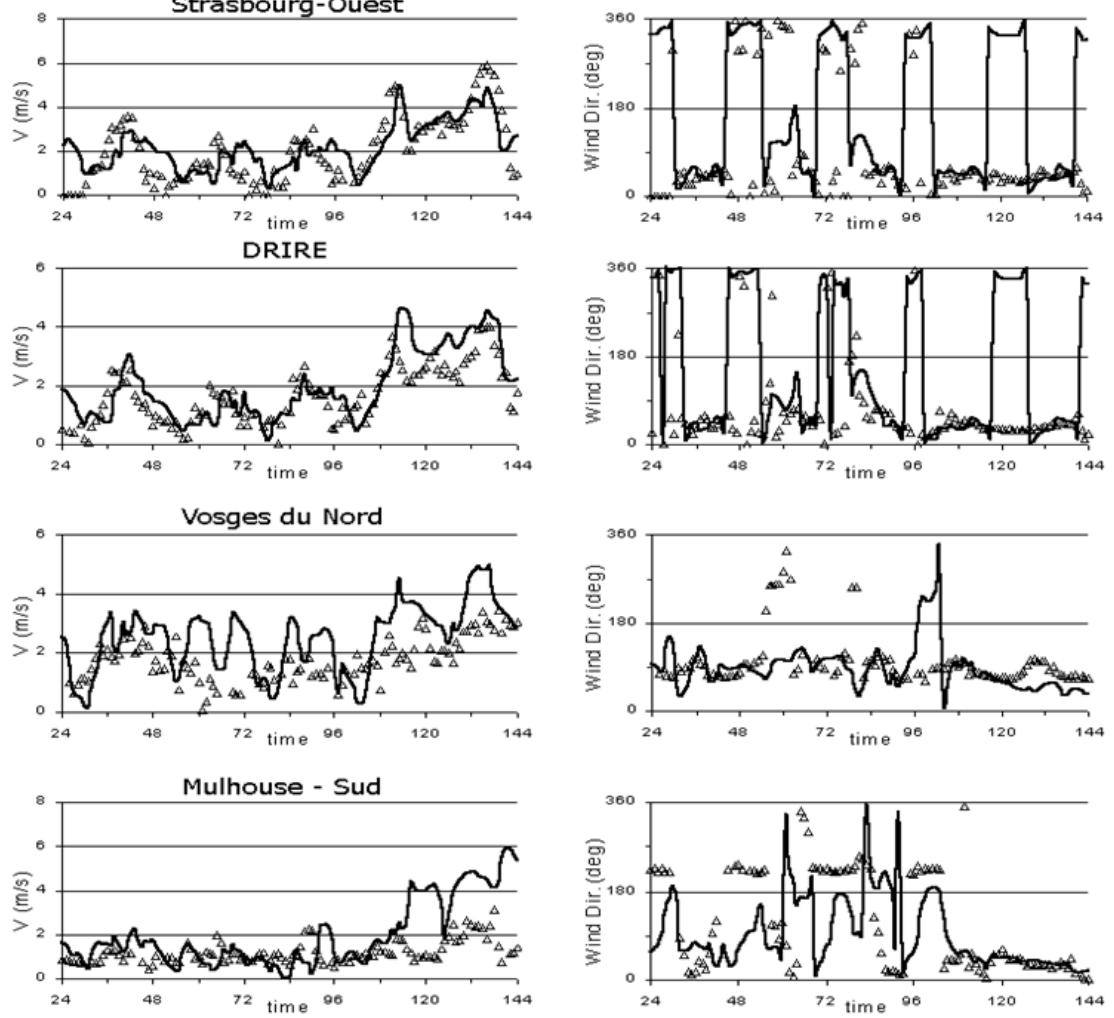

Fig. 2. Evolution of the temperature (first panel from left to right), horizontal wind velocity (second panel) and direction (third panel) for a selection of the Alsacian measuring sites of the ASPA Air Quality survey network. The solid lines indicate the model results. The period represented is the 10 May to 14 May 1998. DRIRE measuring station is located in the centre of the urban area of Strasbourg, StrasbourgOuest and Mulhouse-Sud are suburban measuring sites and Vosges du Nord is a rural one in a forested area located $60 \mathrm{~km}$ North East of Strasbourg (from Ponche and Vinuesa, 2005).

$16.5 \%, 78.1 \%$ and $58.1 \%$ for the VOC, $\mathrm{CO}$ and $\mathrm{NO}_{\mathrm{x}}$ respectively (Table 1). The comparison of these contributions with those on the local scale (see V2003) shows that CO emission contribution is less important at the local scale $(73.4 \%)$ than the regional one, mainly due to the lower regional industrial contributions (fossil fuels have been significantly decreased for 10 years and mainly replaced by natural gas). On the contrary, the regional contributions of $\mathrm{NO}_{\mathrm{x}}$ and $\mathrm{VOC}$ are lesser than those at the local scale (68.6\% and $37.6 \%$ respectively) reflecting the denser urban road traffic contribution on the local scale.

\subsection{Road traffic emission scenarios}

This study is focusing on the impact of modified fuels used by gasoline passenger cars (GPC) and only this contribution of the hourly emission inventories has been modified. The available modified fuels emission factors issued from the UTAC (Union Technique de l'Automobile du motocycle et du Cycle) experiments (Lopez de Rodas and Marduel, 1997) have been used in the whole domain, i.e., Swiss, German and French GPC fleets. The fraction of the vehicles equipped with a three-way catalytic converter is very different from one country to another in 1998: $85 \%$ for Switzerland, $65 \%$ for Germany and 26\% for France. The other road traffic characteristics associated with the emission calculations (traffic volume, diesel passengers cars, light and heavy duty vehicles) were kept constant. The methodology has already been detailed in V2003.

The emission factors are related to a reformulated fuel (socalled R2) and two oxygenated fuel blends (the so-called ETBE1 and ETBE2), both containing 15\% of ETBE. The composition of these fuels is given in Table 2. Briefly, for $\mathrm{R} 2$, the iso-paraffins have been increased (from $40.6 \mathrm{wt} \%$ to $54.9 \mathrm{wt} \%)$ to reduce the aromatic fraction $(49.3 \mathrm{wt} \%$ to $33.6 \mathrm{wt} \%)$. For ETBE1 fuel, $15 \mathrm{wt} \%$ of ETBE has been added, leading to a lowering of all the others compounds such as iso-paraffins (40.6 wt \% to $35.1 \mathrm{wt} \%$ ) and aromatics $(49.3 \mathrm{wt} \%$ to $40.6 \mathrm{wt} \%)$. Finally, for ETBE2, both addition of $15 \%$ of ETBE and reformulation are considered resulting in a slight increase the iso-paraffins (from $40.6 \mathrm{wt} \%$ to $42.5 \mathrm{wt} \%$ ) and lower the aromatic compounds more than for ETBE1 (49.3 wt\% to $31.9 \mathrm{wt} \%$ ). The sulfur content has been adjusted for all the modified fuels to $80 \mathrm{ppb}$. These 
Table 1. Daily emissions of CO, VOC and $\mathrm{NO}_{\mathrm{x}}$ for the INTERREG II area and for 11 May 1998 by source identification classification CORINAIR SNAP94 version 1.1.

\begin{tabular}{lllllll}
\hline Sources & \multicolumn{2}{c}{ CO } & \multicolumn{2}{c}{ VOC } & \multicolumn{2}{c}{$\mathrm{NO}_{\mathrm{x}}$} \\
& tons & $\%$ & tons & $\%$ & tons & \% \\
\hline Combustion in energy and transformation industries & 2.5 & 0.2 & 1.0 & 0.1 & 4.1 & 1.0 \\
Non-industrial combustion plants & 189.0 & 16.4 & 28.9 & 2.7 & 15.9 & 4.0 \\
Combustion in manufacturing industry & 11.9 & 1.0 & 10.9 & 1.0 & 20.5 & 5.1 \\
Production processes & 0.1 & 0.0 & 5.7 & 0.6 & 12.9 & 3.2 \\
Extraction, distribution of fossil fuels, geothermal energy & & & 45.9 & 4.3 & & \\
Solvent and other product use & 0.8 & 0.1 & 212.5 & 20.1 & 2.5 & 0.6 \\
Road transport & 903.5 & 78.1 & 174.3 & 16.5 & 231.2 & 58.1 \\
Other mobile sources and machinery & 17.5 & 1.5 & 5.0 & 0.5 & 18.6 & 4.7 \\
Waste treatment and disposal & 5.6 & 0.5 & 164.8 & 15.6 & 1.5 & 0.4 \\
Agriculture and forestry, land use, wood stock change & & & 321.2 & 30.4 & & \\
Nature & & & 9.2 & 0.9 & & \\
Point sources & 25.8 & 2.2 & 77.2 & 7.3 & 91.0 & 22.9 \\
\hline Total & 1157.1 & 100.0 & 1056.7 & 100.0 & 386.5 & 100.0 \\
\hline
\end{tabular}

Table 2. Characteristics of the fuels. TI is the initial temperature for the beginning of the distillation. T60\% and T95\% represents corresponding temperatures for distilled percentages. E100 report the percentage evaporated at $100^{\circ} \mathrm{C}$. RVP is the Reid Vapor Pressure. RON and MON represent the Research and the Motor Octane Numbers.

\begin{tabular}{lllll}
\hline & REF & R2 & ETBE1 & ETBE2 \\
\hline Density $15^{\circ} \mathrm{C}\left(\mathrm{kg} / \mathrm{m}^{3}\right)$ NFT60-172 & 759.0 & 727.0 & 746.0 & 732.5 \\
RVP $(\mathrm{Kpa})$ NFM07-079 & 59.8 & 64.8 & 57.2 & 65.2 \\
Distillation $\left({ }^{\circ} \mathrm{C}\right)$ NFM07-002 & & & & \\
TI & 32.5 & 31.0 & 31.0 & 29.5 \\
T60\% & 112.5 & 103.0 & 99.5 & 89.0 \\
T95\% & 160.5 & 158.0 & 157.5 & 155.0 \\
E100 $(\%)$ & 42.7 & 48.1 & 50.5 & 58.3 \\
\hline Chemical Composition (m\%) & & & & \\
n-Paraffin & 3.8 & 4.8 & 3.3 & 3.8 \\
Iso-Paraffin & 40.6 & 54.9 & 35.1 & 42.5 \\
Naphtens & 1.4 & 1.5 & 1.1 & 1.3 \\
Aromatics & 49.3 & 33.6 & 40.6 & 31.9 \\
Olefins & 4.7 & 4.9 & 4.3 & 5.4 \\
Oxygenated & 0.1 & 0.2 & 15.7 & 15.1 \\
\hline RON & 98.8 & 97.6 & 101.0 & 100.1 \\
\hline MON & 87.2 & 87.3 & 88.9 & 88.5 \\
\hline
\end{tabular}

formulations has been chosen by the participants of the french program AGRIculture pour le Chimie et l'Energie (ECODEV/AGRICE-CNRS) and the European ALTENER2 program.

The tested vehicle fleet is composed of a Renault Laguna, a Renault Twingo, a Renault R19 and a Peugeot 406 V6 that have already covered a distance of $21000,18000,117500$ and $27000 \mathrm{~km}$ respectively. Only the Renault Laguna and Twingo have an emission-reducing device i.e., a three-way
Table 3. Characteristics of the driving cycle used for the tests.

\begin{tabular}{llll}
\hline Road types & 4xECE15 & EUDC & NEDC \\
\hline Distance $(\mathrm{km})$ & 4.052 & 6.995 & 11.007 \\
Average speed $\left(\mathrm{km} \cdot \mathrm{h}^{-1}\right)$ & 18.7 & 62.6 & 32.7 \\
Maximum speed $\left(\mathrm{km} \cdot \mathrm{h}^{-1}\right)$ & 50 & 120 & 120 \\
\hline
\end{tabular}

converter. The tests were performed according to the NEDC new European driving modes, in which the $40 \mathrm{~s}$ idle period, following the cold start, has been removed. During this cycle, the vehicles covered a distance of $11 \mathrm{~km}$ with an average speed of $33.6 \mathrm{~km} \cdot \mathrm{h}^{-1}$. Two main parts compose the cycle : an urban phase (ECE 15 cycle) repeated four times, including street network, main road and urban highways ( $4 \mathrm{~km}$ with an average speed of $\left.18.7 \mathrm{~km} . \mathrm{h}^{-1}\right)$ and an extra-urban phase ( $7 \mathrm{~km}$ with an average speed of $62.6 \mathrm{~km} \cdot \mathrm{h}^{-1}$ ) which regroups the extra-urban roads and highways (EUDC cycle). All the characteristics are summarized in Table 3.

For the sake of consistency, the emission factors for road traffic used previously in the INTERREG II emission inventory have been replaced by those of the reference fuel REF. Therefore, a direct evaluation of the emission changes between the road traffic contribution in the reference and the modified inventories is suitable. Then, the scenarios are based on the replacement of the reference fuel (REF) by the R2, ETBE1 and ETBE2 fuel blends for different GPC fleet fractions. We have defined nine emission scenarios according to the three types of fuel blends and to three different percentages of the GPC fleet using these fuels $(50,80$ and $100 \%)$. The GPC fleet has been divided into 4 vehicle types with respect to the vehicles tested, depending on the engine capacity and on the presence or absence of catalytic 
Table 4. Aggregated emission factors in $\mathrm{g} \cdot \mathrm{km}^{-1}$ for $\mathrm{NO}_{\mathrm{x}}$, and VOC and for different types of road when $100 \%$ of the fuel-GPC fleet is using the fuel blends REF, ETBE1, ETBE2 and R2.

\begin{tabular}{lcccccc}
\hline \multirow{2}{*}{ Road types } & \multicolumn{2}{c}{ Highway } & \multicolumn{2}{c}{ Road } & \multicolumn{2}{c}{ Urban road } \\
Fuels & $\mathrm{NO}_{\mathrm{x}}$ & $\mathrm{VOC}$ & $\mathrm{NO}_{\mathrm{x}}$ & $\mathrm{VOC}$ & $\mathrm{NO}_{\mathrm{x}}$ & $\mathrm{VOC}$ \\
\hline REF & 0.478 & 0.357 & 0.572 & 2.127 & 0.543 & 8.701 \\
ETBE1 & 0.488 & 0.310 & 0.595 & 1.294 & 0.587 & 3.234 \\
ETBE2 & 0.484 & 0.295 & 0.580 & 1.363 & 0.552 & 3.484 \\
R2 & 0.445 & 0.315 & 0.537 & 1.260 & 0.508 & 3.112 \\
\hline
\end{tabular}

Table 5. Total daily scenario-wide emissions of the $\mathrm{NO}_{\mathrm{x}}$, total VOCs and main VOC splitted compounds (in $\mathrm{kg}$ ) when $100 \%$ of the fuel-GPC fleet is using the fuel blends REF, ETBE1, ETBE2 and R2.

\begin{tabular}{lllll}
\hline & REF & ETBE1 & ETBE2 & R2 \\
\hline $\mathrm{NO}_{\mathrm{x}}$ & 123.9 & 137.9 & 133.4 & 114.7 \\
\hline Total VOCs & 523.5 & 416.3 & 442.8 & 403.1 \\
\hline Methane & 33.1 & 31.8 & 36.2 & 26.8 \\
Ethane & 3.8 & 3.9 & 4.2 & 4.6 \\
Propane & 0.2 & 0.2 & 0.2 & 0.2 \\
Alkanes & 168.2 & 118.4 & 151.0 & 158.6 \\
Ethene & 20.1 & 19.0 & 20.0 & 18.9 \\
Propene & 10.7 & 9.9 & 10.9 & 18.8 \\
Alkenes & 21.7 & 24.3 & 28.3 & 22.3 \\
Acetylene & 37.3 & 36.5 & 33.9 & 26.4 \\
Alkynes & 2.5 & 2.8 & 3.4 & 3.2 \\
Esters & 0.0 & 22.8 & 24.1 & 0.0 \\
Benzene & 10.0 & 7.7 & 7.2 & 6.9 \\
Aromatics & 188.3 & 119.0 & 104.0 & 97.2 \\
Styrenes & 0.4 & 0.4 & 0.2 & 0.1 \\
Formaldehyde & 2.0 & 1.9 & 1.9 & 1.8 \\
Other aldehydes & 3.7 & 5.6 & 5.1 & 3.5 \\
Acetone & 0.2 & 0.9 & 1.0 & 0.6 \\
Ketones & 0.1 & 0.0 & 0.1 & 0.1 \\
Non identified & 21.1 & 11.2 & 11.3 & 12.9 \\
\hline
\end{tabular}

converters. Table 4 shows an example of aggregated emission factors calculated when the whole GPC fleet is using the alternative fuels. One can notice that all the fuels lead to a decrease of VOC emissions. The main difference is that the use of ETBE1 and ETBE2 increases the $\mathrm{NO}_{\mathrm{x}}$ aggregated emission factors. In addition, the VOC emission inventory has been extended to take into account the 128 emitted species measured during the UTAC experiments.

In order to emphasize the differences of the emissions involved by the use of the various fuel-blends, the daily total emission changes when the whole GPC fleet is using such fuels is presented in Table 5. Both ETBE and R2 fuels decrease total VOC emission levels while only R2 allows a decrease of the emissions of $\mathrm{NO}_{\mathrm{x}}$. Alkanes and aromatics are the VOCs for which the emissions are the most affected by the use of alternate fuels. In the case of the use of ETBE, aldehydes, alkenes and ethers also show modifications to a certain extend.

\section{Numerical setup and benchmark simulation}

\subsection{Numerical setup}

The simulations are performed using EZM (EUMAC Zooming Model). This model is divided into two parts: first, the dynamics are calculated by the meteorological mesoscale model MEMO and second, the transport of the reactive chemical species is addressed by the model MARS (see Moussiopoulos (1995) for a complete description).

Since the calculation of the meteorological fields with the MEMO model has already been described in a previous study (Vinuesa et al., 2001), the numerical setup and the results of the simulation are only briefly summarized here. The prescribed grid has $36 \times 54 \times 35$ points in the horizontal and vertical directions, representing a domain of $144 \mathrm{~km} \times 216 \mathrm{~km} \times 6000 \mathrm{~m}$. The calculations have been performed from 9 May to 14 May 1998. The geostrophic wind and the initial vertical potential temperature profiles have been defined using measurements issued by the regional air quality survey network of Alsace (Association de Surveillance et d'étude de la Pollution atmosphérique en Alsace or ASPA) for the first $1200 \mathrm{~m}$ from the ground (which is at about $140 \mathrm{~m}$ above sea level) in the suburban northern part of Strasbourg and, by the Deutsche Wetterdienst (DWD-Stuttgart) in Stuttgart (100 km north-east from Strasbourg) for the altitudes above this height. In Fig. 2, the time evolutions of the temperature (first panel from left to right), horizontal wind velocity (second panel) and wind direction (third panel) for a selection of the Alsacian meteorological sites are presented (see their locations in Fig. 1). The differences obtained in the temperature are mainly due the effect of averaging procedures on the topography and the land-use over $4 \times 4 \mathrm{~km}^{2}$. Nevertheless, the comparison between the measurements and the model results show a good agreement. One can notice that even the change of wind regime, i.e. from low to high geostrophic wind at the end of the week for the north part of the modeling domain, is reproduced with good accuracy.

The boundary conditions and the background concentrations of reactants are taken from the network measurements done by the ASPA-Strasbourg. Measurements from rural stations located in the Vosges Mountains provide the background ozone levels (around $70 \mathrm{ppb}$ ). Since these stations are located in rural areas far away from the sources of pollutants, they satisfy the necessary requirements to be considered as background measurement sites. In addition, the measurements performed in the centre of the valley between Strasbourg and Karlsruhe, the so-called NorthEast Alsace, allow us to take into account the urban plume 

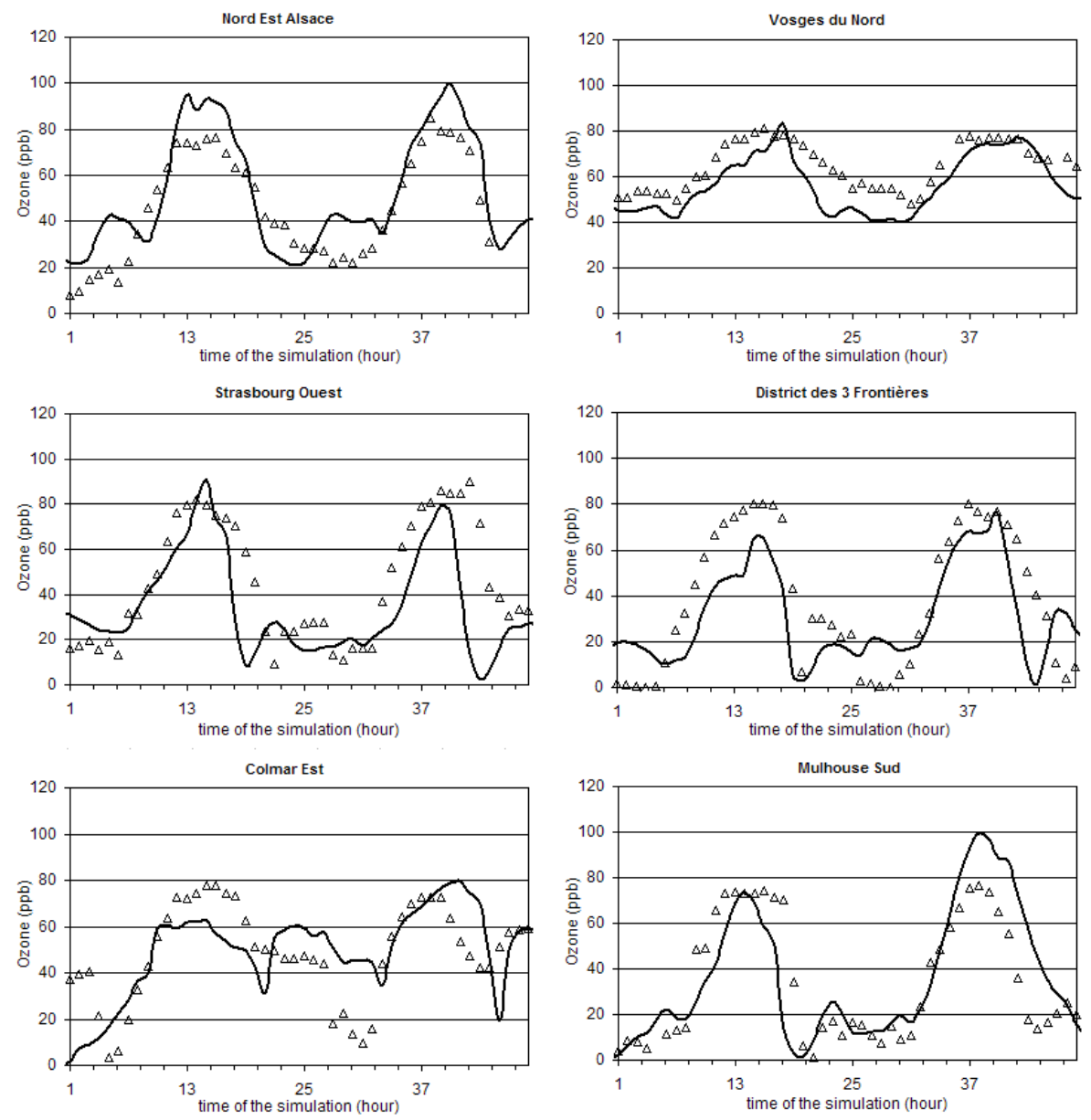

Fig. 3. Evolution of the ozone concentrations for a selection of the Alsacian pollutant measurement sites. The solid lines indicate the model results. The period represented is the 10 May to 11 May 1998. "Nord-Est Alsace" and "Vosges du Nord" stations correspond to rural and mountainous sites located $60 \mathrm{~km}$ north east of Strasbourg and $90 \mathrm{~km}$ north of Strasbourg respectively. "Strasbourg-Ouest", "Colmar-Est", and "Mulhouse-Sud" correspond to semi-urban measuring stations. The measuring station "District des 3 frontières" is also an semi urban one, located close to the Swiss-German- French border, south east of the domain.

coming form Karlsruhe region. Using these data, the $\mathrm{NO}_{\mathrm{x}}$ boundary conditions were set at $9 \mathrm{ppb}$. The simulation with the chemical transport model MARS covers a 48-h period starting on 10 May 1998 at $0 \mathrm{~h} 00$ Local Standard Time (LST). Only the calculation results obtained for the second day has been considered assuming that $24 \mathrm{~h}$ of prerun are enough to provide realistic background concentrations. The chemical mechanism used is a modified version of RACM (Stockwell et al., 1997) where reactions accounting for the degradation scheme of ETBE were previously implemented. The degradation scheme of ETBE by HO has been added to the RACM mechanism with a rate constant of $9.73 \times 10^{-12} \mathrm{~cm}^{3}$ molecule $\mathrm{s}^{-1} \mathrm{~s}^{-1}$ (Smith et al., 1992; Kirchner, 1999). In addition, the degradation of the tertio-butyl formate (TBF), a product of the previous reaction, has been added, with a rate constant of $7.4 \times 10^{-13} \mathrm{~cm}^{3}$ molecule ${ }^{-1} \mathrm{~s}^{-1}$ (Kirchner, 1999). Reactions (1) and (2) are budget reactions and reads, according to the RACM chemical species:

$$
\begin{aligned}
& \mathrm{ETBE}+\mathrm{OH} \rightarrow 0.13 \mathrm{HC} 5+0.54 \mathrm{TBF}+0.87 \mathrm{HCHO} \\
& +0.87 \mathrm{XO}_{2}+0.80 \mathrm{HO}_{2}+0.20 \mathrm{MO}_{2}+0.18 \mathrm{ALD} \\
& +0.18 \mathrm{KET}+0.04 \mathrm{HC}_{3}
\end{aligned}
$$

$\mathrm{TBF}+\mathrm{OH} \rightarrow 0.3\left(\mathrm{ALD}+\mathrm{HO}_{2}+\mathrm{XO}_{2}\right)+0.7 \mathrm{ACO}_{3}$,

where the model species $\mathrm{HC}_{3}$ and $\mathrm{HC}_{5}$ regroup alkanes, alcohols, esters and alkynes. $\mathrm{XO}_{2}$ accounts for additional $\mathrm{NO}$ to $\mathrm{NO}_{2}$ conversions, $\mathrm{MO}_{2}$ represents methyl peroxy radical and $\mathrm{ACO}_{3}$ regroups all the acetyl peroxy and higher saturated acyl peroxy radicals. Further details can be found in Atkinson (1994), Kirchner et al. (1997) and V2003.

\subsection{Base case simulation}

The reference emission scenarios have been recalculated using emission factors determined for the reference fuel (REF) and driving modes previously presented (see Sect. 2). In spite 

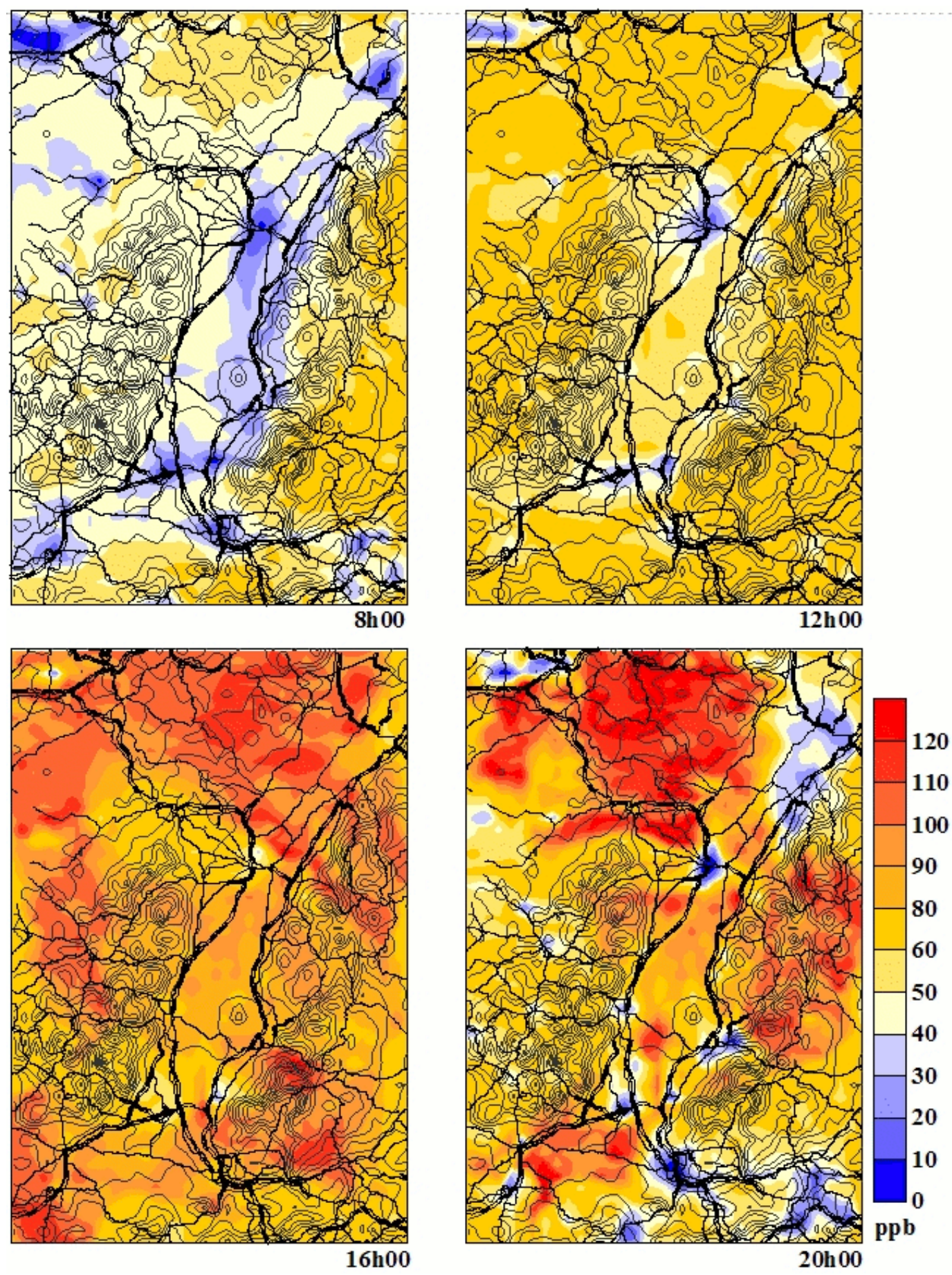

Fig. 4. Ozone concentrations fields calculated at $8 \mathrm{~h} 00,12 \mathrm{~h} 00,16 \mathrm{~h} 00$ and $20 \mathrm{~h} 00 \mathrm{LST}$ (Local Standard Time). Heavy traffic roads in dark lines and topography in grey lines are represented for convenience.

of the resulting changes compared to the real case, the reference case gives similar concentration fields then the ones analyzed by Ponche and Vinuesa (2005) and the time evolution of the ozone concentration for a selection of the Alsacian meteorological sites as reproduced in Fig. 3 show a good agreement with the measurements.
Figure 4 shows the ozone concentration fields at $8 \mathrm{~h} 00$, $12 \mathrm{~h} 00,16 \mathrm{~h} 00$ and $20 \mathrm{~h} 00$ LST. One can notice that the depletion process of ozone is favored in the morning. The most important ozone depletion zones are located in the urban areas and along the main road network where high NO emissions occur (morning traffic peak). Even at $8 \mathrm{~h} 00 \mathrm{LST}$, the 

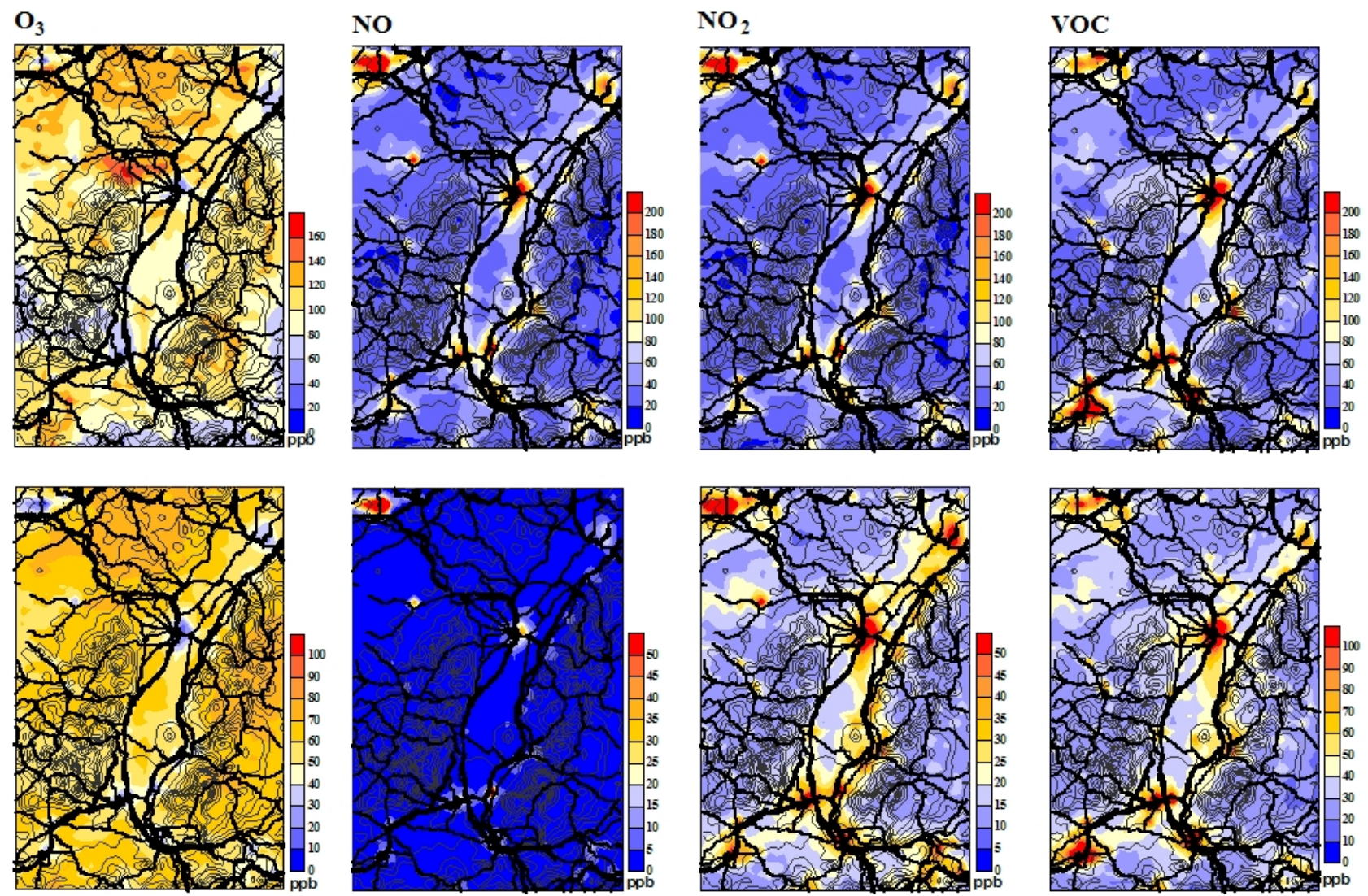

Fig. 5. Hourly maximum concentrations HMC (upper row) and daily average concentrations DAC (lower row) for ozone, nitrogen oxide, nitrogen dioxide, and volatile organic compounds calculated with the reference emission scenario (REF). Heavy traffic roads in dark lines and topography in grey lines are represented for convenience.

ozone levels in rural areas are still under the control of the background conditions with low NO levels. Thus NO is preferentially oxidized via the VOC-oxidation process and the residual ozone in the mountainous areas resulting from the photochemical activity of the previous day remains with high levels. From $12 \mathrm{~h} 00 \mathrm{LST}$, the ozone production from precursors contained in urban plumes and its low depletion over poor NO concentration areas results in the increase of its background concentrations. Consequently, first, the maximum ozone levels are reached in the afternoon and in the evening, and then the highest levels are located outside the urban plume areas, i.e. in the rural and mountainous zones.

Similar conclusions can be drawn from Fig. 5 where the hourly maximum concentrations (HMC) and the daily averaged concentrations (DAC) for ozone, $\mathrm{NO}_{\mathrm{x}}$ and $\mathrm{VOC}$ are presented. Notice that the HMC and DAC maps allow locating the concentration peaks and the background levels respectively and that HMC map is a so-called composite map since the concentration peaks can be reached at different times. The spatial distribution of the HMC and DAC over the domain is quite similar for each pollutant. For $\mathrm{NO}_{\mathrm{x}}$, their values are strongly correlated with the level of urbanization of the area and also with the road network. For $\mathrm{O}_{3}$ and the VOC, the correlation between concentration levels and road traffic is hardly established since $\mathrm{O}_{3}$ is a secondary pollutant and road traffic contributes only to $16.5 \%$ of the VOC emissions. One can notice different HMC/DAC ratio behavior. Especially for NO, the ratio HMC/DAC is very high compared to that of the other pollutants and very high ratio can be noticed in the urban areas and the rural areas close to the main roads. This points out that its levels are mainly related to road traffic emissions since these latters are intermittent during the day. Also high HMC/DAC ratios are found in the neighborhood of the urban plumes and especially the one of Strasbourg suggesting a strong connection between road traffic emission and ozone production. Indeed, in those regions, the levels of NO are too low to deplete the ozone produced by its precursors induced by road traffic emissions. In the center of the valley and in urban area where NO levels are sufficient to limit the ozone generation, we found the lowest HMC and DAC levels. 

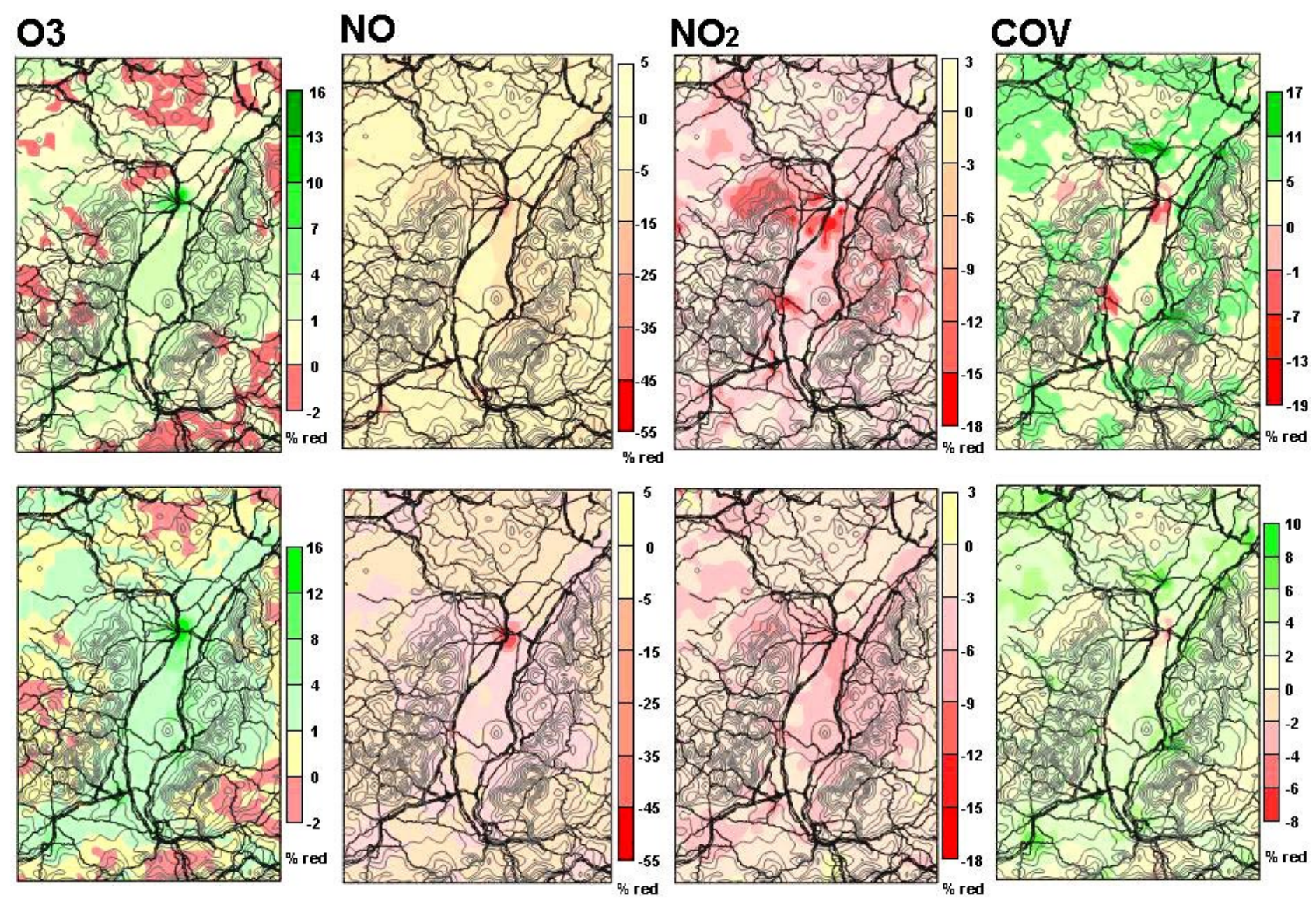

Fig. 6. Results obtained when $100 \%$ of the GPC is using ETBE1 fuel. Reduction percentages of maximum concentration levels RIM (upper row) and reduction percentages of daily average concentration levels RIA (lower row) for ozone, nitrogen oxide, nitrogen dioxide, and volatile organic compounds. Heavy traffic roads in dark lines and topography in grey lines are represented for convenience.

\section{Effects of the modified fuel blends on regional air quality}

We focus our discussion on the hourly averaged maximum concentrations (HMC) and the daily average concentrations (DAC) since they provide useful information on peak levels and background concentrations respectively. However, its appears more convenient to quantify directly the modifications of these quantities induced by the use of alternative fuels. Therefore we introduce the following relative impact factors on the HMC and the DAC, the so-called relative impact factor on the hourly maximum concentrations (RIM) and relative impact factor on the daily average concentrations (RIA) respectively,

$$
\begin{aligned}
& \mathrm{RIM}=\frac{\left(\mathrm{HMC}_{\mathrm{ref}}-\mathrm{HMC}_{\mathrm{sc}}\right)}{\mathrm{HMC}_{\mathrm{ref}}}, \\
& \mathrm{RIA}=\frac{\left(\mathrm{DAC}_{\mathrm{ref}}-\mathrm{DAC}_{\mathrm{sc}}\right)}{\mathrm{DAC}_{\mathrm{ref}}} .
\end{aligned}
$$

The RIM and RIA are calculated for each grid-cell. The indices ref and sc refer to the reference simulation and the scenarios, respectively. Positive (negative) values correspond to lower (or higher) concentrations simulated using the emission scenario compared to the base case simulation. Note that this definition allows to clearly distinguish between improvement (positive values) and degradation (negative values) of the air quality.

Figure 6 shows the RIM and RIA for ozone, $\mathrm{NO}, \mathrm{NO}_{2}$ and VOC when $100 \%$ of the GPC fleet is using ETBE1 fuel. The levels of nitrogen oxides show a dramatic increase. At the regional scale, the NO maximum and background concentrations are increased (between $0 \%$ and $-5 \%$ for both RIA and RIM). In city plumes, the increases can reach between $-15 \%$ and $-50 \%$ for both relative impact factors. The same observation can be made for $\mathrm{NO}_{2}$ even if the impacts are less important. As a result, the effect of using ETBE1 fuel on the $\mathrm{NO}_{\mathrm{x}}$ RIA and RIM levels is significantly unfavorable. The concentration levels of $\mathrm{NO}_{\mathrm{x}}$ are correlated with the emission from road traffic. Indeed the main areas affected by the changes in $\mathrm{NO}_{\mathrm{x}}$ emission factors are the urban and suburban zones. Significant increases in the impact factors in urban plumes are directly related to the increase in the emission 
factors. In that sense, the impacts of using ETBE1 fuel on $\mathrm{NO}_{\mathrm{x}}$ are directly correlated with the location of the emissions.

Favorable impacts (i.e., positive RIM and RIA) on the $\mathrm{VOC}$ at the regional scale can be noticed. Indeed, the reduction in HMC and DAC can reach $10 \%$ locally. Compared to the $\mathrm{NO}_{\mathrm{x}}$, there is no direct spatial correlation between VOC emission from road traffic and impact factors. Even if the changes in emission levels are related to road traffic, there is no relevant impact close to the emission sources. On the contrary, the most important impacts are located in rural areas, and away from urban and road plumes. These results suggest that the background VOC concentration levels are mainly affected by the reduction of the emitted VOC more subject to the oxidation by $\mathrm{HO}$ radicals. However, some increases can be located in the east of Strasbourg and Colmar; between $-1 \%$ and $-13 \%$ for the HMC and between $-2 \%$ and $-4 \%$ for the DAC and the use of ETBE1 fuel only show a small impact on VOC levels in city plumes. In these regions, where VOC emissions are reduced, we found very high increases of $\mathrm{NO}_{\mathrm{x}}$ levels and high decrease in ozone levels suggesting that the $\mathrm{NO}_{\mathrm{x}}$-oxidation pathway is favored with respect to the oxidation of VOC. This effect combined with the transport of VOC originated from urban sources result in the smaller decrease and even locally some increases of VOC levels.

Ozone levels are decreased both in terms of peak and background concentrations. The main positive impacts are located in urban areas, such as Strasbourg and Mulhouse, with reductions reaching more than $10 \%$ locally. Some important impacts can also be located in the vicinity of the core of the valley for the RIM and in its centre for the RIA. In urban areas, the use of ETBE1 fuel results in a $63 \%$ reduction of VOC emissions (see Table 4). Since there are less VOC available for the oxidation of $\mathrm{NO}$ in $\mathrm{NO}_{2}$ and $\mathrm{NO}$ levels are increased, the depletion of ozone by NO within the NOoxidation pathway is the main process controlling ozone RIA and RIM. As a result, the most important reduction in the impact factors takes place in such areas. The same analysis can be done in the vicinity of roads and highways. However, the small impact and sometime increase of VOC levels in urban plumes reduces the benefits of using ETBE1 to lower ozone levels in these particular areas. In other rural areas, only weak reductions of ozone levels are reported since the reduction of VOC mainly benefits to the less reactive ones and NO level show only a increase not enough important to favor the $\mathrm{NO}_{\mathrm{x}}$-oxidation and the titration of $\mathrm{NO}$ by ozone. This clearly shows that the emissions from road traffic control the ozone levels at the local scale, and in the vicinity of the sources. On the contrary, at the regional scale and except in urban plumes, it also seems that road traffic does not have a significant impact on rural ozone levels.

Since the impacts show a near-linear effect with respect to fractional change in the fleet penetration, only the results concerning $50 \%$ and $100 \%$ of the GPC fleet using alternative fuels are shown in Tables 6 and 7. Table 6 quantifies the impacts of the use of oxygenated additives (ETBE1 and ETBE2) and reformulated fuel (R2) on ozone, $\mathrm{NO}, \mathrm{NO}_{2}$ and VOC. It shows the maximum, the minimum, the average over the whole area and the standard deviation of the RIM and the RIA, respectively. For both impact factors and for all the compounds, the maximum effects can be seen when $100 \%$ of the GPC fleet uses the alternative fuel-blends. For all the scenarios, the ozone levels are lowered and the most favorable fuel blend is the ETBE1, which shows a decrease of $2.02 \%$ and $1.88 \%$ for the RIM and the RIA, respectively. This fuel is also showing the greatest decrease in VOC levels and the biggest increase on $\mathrm{NO}_{\mathrm{x}}$ levels for both impact factors. By examining the only-reformulated fuel R2 and the reformulated and oxygenated fuel ETBE2, it appears that R2 is giving the most favorable impact factors in terms of $\mathrm{NO}_{\mathrm{x}}$ and VOC levels. As an example, the corresponding RIA are $-2.13 \%,-1.21 \%$ and $2.67 \%$ for $\mathrm{NO}, \mathrm{NO}_{2}$ and VOC, respectively. By reducing NO levels, the oxidation of NO by ozone becomes less likely and less ozone is depleted leading to the lowest impact on ozone levels when comparing to the other fuels. For ETBE2 that is both oxygenated and reformulated, the RIA for $\mathrm{NO}, \mathrm{NO}_{2}$ and VOC read $-3.88 \%$, $-2.39 \%$ and $1.99 \%$, respectively. This increase of NO and the reduction of the most reactive VOC (see Table 7), favors the $\mathrm{NO}_{\mathrm{x}}$-oxidation pathway. As a result, a bigger reduction in ozone levels is found compared to R2 but smaller compared to ETBE1 for which the $\mathrm{NO}$ and $\mathrm{NO}_{2}$ RIM read $-5.13 \%$ and $-3.09 \%$, respectively.

We have noticed previously that the averaged impact factors of $\mathrm{NO}_{\mathrm{x}}$ are directly correlated with the emission factors. Indeed, the lowest increases of RIM and RIA are reported for the lowest emission factors (R2) and the highest increases are observed for ETBE1. Since the splitting of the VOC plays an important role in ozone depletion and production processes, one will find the quantitative impacts of using the alternative fuels on several VOCs in Table 7. This table shows the averaged values over the whole area and the standard deviations of the RIM and the RIA. Apart from the methane, the alkenes and the generic aldehydes, all the scenarios lead to a general decrease of the concentration peaks and the background concentrations. The levels of alkenes are increasing for almost all the scenarios. The same impact can be observed for the generic aldehydes for only ETBE1 and ETBE2. Notice that a negative impact on methane levels is induced only by the fuel ETBE2. The higher reactive alkane and aromatic levels reveal the most important positive impacts. These reductions are related to the reformulation of the fuels, which is linked to lower emissions due to reduction of the corresponding aggregated emission factors. In particular, in urban areas where the impacts for such compounds reach their maximum, the emission factors are reduced by more than $50 \%$.

In order to estimate the sensitivity of the results presented previously and to distinguish which characteristic of the emission (amount or reactivity) is driving these results, we have defined 4 extra emission scenarios. These scenar- 
Table 6. Quantitative impacts of the use of oxygenated additives (ETBE1 and ETBE2) and reformulated fuel (R2) on ozone, carbon monoxide, $\mathrm{NO}, \mathrm{NO}_{2}$ and volatile organic compounds concentrations. For all species, the impacts on hourly maximum concentrations (RIM) and the daily average concentrations (RIA) are given in percentage. Positive (negative) values correspond to a decrease (increase) of the RIM and RIA.

\begin{tabular}{|c|c|c|c|c|c|c|c|}
\hline \multirow{2}{*}{\multicolumn{2}{|c|}{$\begin{array}{l}\text { Fuel blends } \\
\text { GPC fleet (\%) }\end{array}$}} & \multicolumn{2}{|c|}{ ETBE1 } & \multicolumn{2}{|c|}{ ETBE2 } & \multicolumn{2}{|c|}{$\mathrm{R} 2$} \\
\hline & & 50 & 100 & 50 & 100 & 50 & 100 \\
\hline \multicolumn{8}{|c|}{ RIM } \\
\hline \multirow[t]{4}{*}{$\mathrm{O}_{3}$} & Maximum & 8.67 & 16.28 & 6.84 & 12.76 & 5.38 & 10.17 \\
\hline & Minimum & -2.64 & -4.57 & -1.56 & -2.20 & -1.52 & -2.34 \\
\hline & Mean & 1.09 & 2.02 & 0.71 & 1.26 & 0.58 & 1.05 \\
\hline & $\sigma$ & 1.00 & 1.83 & 0.66 & 1.16 & 0.56 & 1.00 \\
\hline \multirow[t]{4}{*}{ NO } & Maximum & 29.49 & 50.94 & 1.80 & 3.84 & 1.47 & 2.69 \\
\hline & Minimum & -27.00 & -60.51 & -19.56 & -41.49 & -14.94 & -30.81 \\
\hline & Mean & -2.25 & -5.03 & -1.59 & -3.83 & -0.82 & -2.05 \\
\hline & $\sigma$ & 2.19 & 4.70 & 1.45 & 3.25 & 1.03 & 2.27 \\
\hline \multirow[t]{4}{*}{$\mathrm{NO}_{2}$} & Maximum & 28.87 & 57.60 & 0.54 & 1.15 & 1.03 & 1.39 \\
\hline & Minimum & -10.21 & -19.63 & -9.00 & -17.57 & -7.48 & -14.83 \\
\hline & Mean & -1.87 & -4.40 & -1.42 & -3.45 & -0.59 & -1.80 \\
\hline & $\sigma$ & 1.52 & 3.20 & 1.08 & 2.27 & 0.77 & 1.59 \\
\hline \multirow[t]{4}{*}{ VOC } & Maximum & 11.24 & 19.95 & 8.42 & 16.59 & 9.61 & 18.54 \\
\hline & Minimum & -7.15 & -16.49 & -9.35 & -21.33 & -7.84 & -18.50 \\
\hline & Mean & 3.53 & 4.98 & 2.48 & 2.84 & 2.91 & 3.96 \\
\hline & $\sigma$ & 2.01 & 2.88 & 1.76 & 2.52 & 1.81 & 2.61 \\
\hline \multicolumn{8}{|c|}{ RIA } \\
\hline \multirow[t]{4}{*}{$\mathrm{O}_{3}$} & Maximum & 9.97 & 18.66 & 8.09 & 15.32 & 6.15 & 11.76 \\
\hline & Minimum & -7.25 & -14.78 & -0.19 & -0.45 & -0.20 & -0.27 \\
\hline & Mean & 0.93 & 1.88 & 0.64 & 1.29 & 0.43 & 0.91 \\
\hline & $\sigma$ & 0.86 & 1.69 & 0.61 & 1.23 & 0.46 & 0.92 \\
\hline \multirow[t]{4}{*}{ NO } & Maximum & 31.04 & 56.36 & 0.68 & 1.51 & 0.34 & 0.88 \\
\hline & Minimum & -27.14 & -56.36 & -13.84 & -28.73 & -11.06 & -22.70 \\
\hline & Mean & -2.37 & -5.13 & -1.58 & -3.88 & -0.90 & -2.13 \\
\hline & $\sigma$ & 1.85 & 3.92 & 1.21 & 2.68 & 0.87 & 1.87 \\
\hline \multirow[t]{4}{*}{$\mathrm{NO}_{2}$} & Maximum & 20.67 & 41.44 & 0.42 & 1.15 & 0.36 & 0.55 \\
\hline & Minimum & -12.35 & -22.63 & -5.76 & -11.52 & -4.38 & -8.96 \\
\hline & Mean & -1.32 & -3.09 & -0.98 & -2.39 & -0.39 & -1.21 \\
\hline & $\sigma$ & 0.96 & 2.01 & 0.61 & 1.33 & 0.41 & 0.89 \\
\hline \multirow[t]{4}{*}{ VOC } & Maximum & 8.18 & 12.44 & 6.16 & 10.15 & 6.96 & 11.43 \\
\hline & Minimum & -3.36 & -8.12 & -4.68 & -11.07 & -3.72 & -9.13 \\
\hline & Mean & 2.31 & 3.31 & 1.67 & 1.99 & 1.92 & 2.67 \\
\hline & $\sigma$ & 1.14 & 1.67 & 0.94 & 1.34 & 1.00 & 1.46 \\
\hline
\end{tabular}

ios are based on systematic reductions or increases in the contribution of road traffic: increase/decrease of $10 \%$ of $\mathrm{NO}_{\mathrm{x}}$ emissions from the GPC fleet (SCE1+/SCE1-) and increase/decrease of $10 \%$ of VOC emissions from the GPC fleet (SCE2+/SCE2-). The results of these scenarios are given in Table 8. The mean values of the peak and background concentration of the $\mathrm{NO}_{\mathrm{x}}$ are directly correlated with the emission levels. For instance, the SCE1+ leads to an increase of $2.34 \%$ and $2.07 \%$ of the $\mathrm{NO}$ and $\mathrm{NO}_{2}$ RIA, respectively and the SCE1 - gives $\mathrm{NO}$ and $\mathrm{NO}_{2}$ RIA decreases of $2.22 \%$ and $2.10 \%$ while the SCE2+/SCE2- scenarios give impacts one order of magnitude less important. One will notice the same behavior for the VOCs. The main interest of these scenarios is to show the impact of these controlled emission reductions on the ozone levels, which are low (less than $0.8 \%$ ) compared to emission scenarios using alternative fuels. Since the use of both ETBE fuel-blends reduce the total scenario wide emissions of VOC but increase the ones of $\mathrm{NO}_{\mathrm{x}}$ (Table 5), these scenarios can be considered as scenariolike combination of SCE1+ and SCE2-. The corresponding scenario-like for R2 combines SCE1- and SCE2-. Since the sensitivity analysis shows that an improvement of regional ozone levels can be obtained by increasing $\mathrm{NO}_{\mathrm{x}}$ emissions or reducing total VOC emissions, the main differences 
Table 7. Quantitative impacts on hourly maximum concentrations (RIM) and daily average concentrations (RIA) for several VOCs. The average over the whole domain and the standard deviation $\sigma$ are given.

\begin{tabular}{|c|c|c|c|c|c|c|c|}
\hline \multirow{2}{*}{$\begin{array}{c}\text { Fuel blends } \\
\text { GPC fleet }(\%)\end{array}$} & & \multicolumn{2}{|c|}{ ETBE1 } & \multicolumn{2}{|c|}{ ETBE2 } & \multicolumn{2}{|c|}{$\mathrm{R} 2$} \\
\hline & & 50 & 100 & 50 & 100 & 50 & 100 \\
\hline \multicolumn{8}{|c|}{ RIM } \\
\hline \multirow[t]{2}{*}{ Methane } & Mean & 0.13 & 0.19 & -0.17 & -0.39 & 0.12 & 0.17 \\
\hline & $\sigma$ & 0.18 & 0.29 & 0.27 & 0.61 & 0.18 & 0.31 \\
\hline \multirow[t]{2}{*}{ Ethane } & Mean & 6.35 & 7.98 & 1.93 & -1.33 & 5.35 & 6.19 \\
\hline & $\sigma$ & 3.43 & 5.09 & 3.40 & 5.97 & 3.33 & 5.15 \\
\hline \multirow[t]{2}{*}{ Low Reactive Alkanes } & Mean & 1.63 & 2.44 & 0.75 & 0.73 & 0.59 & 0.58 \\
\hline & $\sigma$ & 1.12 & 1.66 & 0.77 & 1.12 & 0.70 & 1.09 \\
\hline \multirow[t]{2}{*}{ Moderately Reactive Alkanes } & Mean & 4.50 & 6.76 & 2.10 & 2.18 & 1.29 & 1.03 \\
\hline & $\sigma$ & 2.45 & 3.59 & 1.64 & 2.31 & 1.39 & 2.13 \\
\hline \multirow{2}{*}{ Highly Reactive Alkanes, Aromatics } & Mean & 12.51 & 18.57 & 14.98 & 23.51 & 16.29 & 25.70 \\
\hline & $\sigma$ & 4.08 & 6.03 & 4.30 & 6.27 & 4.35 & 6.36 \\
\hline \multirow{2}{*}{ Ethene } & Mean & 6.36 & 7.83 & 1.91 & -1.57 & 5.46 & 6.22 \\
\hline & $\sigma$ & 3.71 & 5.50 & 3.60 & 6.23 & 3.57 & 5.47 \\
\hline \multirow{2}{*}{ Others Alkenes } & Mean & 0.43 & -0.65 & -1.06 & -3.84 & -0.18 & -1.35 \\
\hline & $\sigma$ & 2.19 & 4.06 & 2.89 & 6.39 & 2.04 & 3.80 \\
\hline \multirow[t]{2}{*}{ Formaldehyde } & Mean & 1.65 & 2.20 & 0.61 & -0.12 & 0.96 & 0.95 \\
\hline & $\sigma$ & 1.01 & 1.58 & 1.13 & 2.23 & 0.89 & 1.58 \\
\hline \multirow[t]{2}{*}{ Others Aldehydes } & Mean & 0.51 & -0.25 & 0.08 & -1.24 & 1.40 & 1.64 \\
\hline & $\sigma$ & 1.41 & 2.72 & 1.37 & 2.76 & 1.19 & 1.78 \\
\hline \multirow[t]{2}{*}{ Ketones } & Mean & 3.50 & 5.56 & 3.04 & 4.69 & 3.06 & 4.82 \\
\hline & $\sigma$ & 1.67 & 2.61 & 1.48 & 2.30 & 1.44 & 2.20 \\
\hline \multirow[t]{2}{*}{ PAN } & Mean & 2.32 & 3.87 & 1.47 & 2.17 & 1.48 & 2.40 \\
\hline & $\sigma$ & 1.72 & 2.86 & 1.06 & 1.60 & 1.08 & 1.70 \\
\hline \multicolumn{8}{|c|}{ RIA } \\
\hline \multirow[t]{2}{*}{ Methane } & Mean & 0.08 & 0.12 & -0.09 & -0.22 & 0.07 & 0.11 \\
\hline & $\sigma$ & 0.08 & 0.14 & 0.13 & 0.28 & 0.08 & 0.14 \\
\hline \multirow[t]{2}{*}{ Ethane } & Mean & 6.14 & 7.82 & 2.17 & -0.57 & 5.24 & 6.20 \\
\hline & $\sigma$ & 2.20 & 3.18 & 2.10 & 3.76 & 2.11 & 3.20 \\
\hline \multirow[t]{2}{*}{ Low Reactive Alkanes } & Mean & 1.07 & 1.63 & 0.53 & 0.56 & 0.43 & 0.46 \\
\hline & $\sigma$ & 0.66 & 1.01 & 0.41 & 0.60 & 0.37 & 0.57 \\
\hline \multirow[t]{2}{*}{ Moderately Reactive Alkanes } & Mean & 4.31 & 6.51 & 2.11 & 2.29 & 1.35 & 1.23 \\
\hline & $\sigma$ & 1.38 & 2.07 & 0.95 & 1.41 & 0.82 & 1.32 \\
\hline Highly Reactive Alkanes, Aromatics & Mean & 11.77 & 17.58 & 14.06 & 22.11 & 15.21 & 24.09 \\
\hline & $\sigma$ & 2.61 & 3.91 & 2.77 & 4.12 & 2.84 & 4.21 \\
\hline Ethene & Mean & 6.19 & 7.79 & 2.19 & -0.70 & 5.39 & 6.36 \\
\hline & $\sigma$ & 2.44 & 3.54 & 2.30 & 4.10 & 2.31 & 3.51 \\
\hline Others Alkenes & Mean & 0.39 & -0.60 & -1.03 & -3.56 & -0.29 & -1.39 \\
\hline & $\sigma$ & 1.67 & 3.10 & 2.18 & 4.91 & 1.72 & 3.10 \\
\hline Formaldehyde & Mean & 1.22 & 1.68 & 0.57 & 0.16 & 0.65 & 0.63 \\
\hline & $\sigma$ & 0.63 & 0.93 & 0.60 & 1.03 & 0.45 & 0.73 \\
\hline Others Aldehydes & Mean & 0.25 & -0.32 & 0.11 & -0.75 & 1.10 & 1.39 \\
\hline & $\sigma$ & 0.62 & 1.33 & 0.56 & 1.25 & 0.72 & 1.02 \\
\hline Ketones & Mean & 2.43 & 3.81 & 2.12 & 3.18 & 2.17 & 3.39 \\
\hline & $\sigma$ & 1.03 & 1.63 & 0.89 & 1.37 & 0.88 & 1.36 \\
\hline PAN & Mean & 1.75 & 3.06 & 1.06 & 1.60 & 1.09 & 1.86 \\
\hline & $\sigma$ & 1.11 & 1.88 & 0.66 & 1.00 & 0.68 & 1.11 \\
\hline
\end{tabular}


Table 8. Quantitative impacts of the sensitivity analysis scenarios on ozone, nitrogen oxides and volatile organic compound concentrations. The average over the whole domain and the standard deviation $\sigma$ are given.

\begin{tabular}{llllllllll}
\hline \multicolumn{9}{c}{} & \multicolumn{9}{c}{ RIM } & \multicolumn{4}{c}{ RIA } \\
\hline & & SCE1+ & SCE1- & SCE2+ & SCE2- & SCE1+ & SCE1- & SCE2+ & SCE2- \\
\hline $\mathrm{O}_{3}$ & Mean & 0.78 & -0.78 & -0.42 & 0.42 & 0.79 & -0.80 & -0.25 & 0.25 \\
& $\sigma$ & 0.68 & 0.69 & 0.39 & 0.38 & 0.62 & 0.63 & 0.20 & 0.20 \\
$\mathrm{NO}$ & Mean & -2.34 & 2.22 & 0.21 & -0.25 & -2.50 & 2.15 & 0.24 & -0.33 \\
& $\sigma$ & 1.69 & 1.58 & 0.47 & 0.25 & 1.28 & 1.23 & 0.26 & 0.26 \\
$\mathrm{NO}_{2}$ & Mean & -2.07 & 2.10 & 0.11 & -0.10 & -1.54 & 1.54 & 0.08 & -0.08 \\
& $\sigma$ & 1.20 & 1.22 & 0.25 & 0.19 & 0.71 & 0.71 & 0.08 & 0.08 \\
VOC & Mean & -0.01 & 0.03 & -2.58 & 2.55 & -0.03 & 0.01 & -1.62 & 1.61 \\
& $\sigma$ & 0.20 & 0.21 & 1.10 & 1.10 & 0.02 & 0.03 & 0.71 & 0.71 \\
\hline
\end{tabular}

in the results obtained between $\mathrm{R} 2$ and ETBE based scenario are due to the level of $\mathrm{NO}_{\mathrm{x}}$ emissions. However, the simultaneous changes in total $\mathrm{NO}_{\mathrm{x}}$ and $\mathrm{VOC}$ emission levels makes difficult to derive a reactivity effect of the emission changes on the impacts.

\section{Comparison of the results at the regional and local scales}

As mentioned previously, V2003 studied the effect of using the same alternative gasoline fuel blends, i.e. ETBE1, ETBE2 and R2, on the air quality of an urban area. Since we are using the same methodology, the same meteorological fields and constant boundary conditions (i.e., in space and time) for the pollutant concentrations that allowed reproducing the base case, i.e. the ozone pollution episode of May 1998, with a very good agreement with measurements, it is reasonable to compare the results obtained at local scale with those obtained from the present study by focusing on the Strasbourg area. By this way, it might be possible to draw some general inferences on the effects of the use of alternative fuels on the long-range transport of pollutants and on its contribution to the local and urban air quality.

However, one should notice that the emission inventories and the spatial resolution of the two studies differ. Since we are mainly interested in relative impacts than intrinsic concentrations and that the same methodology is used, the impact of using different emission inventories to build the emission scenarios should be limited. A more problematic issue, and one that deserves discussion, is the following. In air quality modeling, the emissions are averaged over each grid cell where emission sources exist and are located. The source can be linear (e.g. roads), surface (fields or urban areas) or punctual (factory) but after the averaging procedure, it is considered as a surface source for which the emissions are homogeneously distributed over the grid cell. Since the atmospheric chemistry is a highly nonlinear process, the artificial dilution effect due to this averaging procedure can induce different concentration predictions than the ones obtained for a real uniform emission situation (Mathur and Peters, 1992; Sillman et al., 1990). Here also, since we are interested in relative impacts, we assume that this dilution effect has no relevant impact on the results.

V2003 showed that the use of alternative fuels at a local scale leads to a significant reduction of VOC urban levels, but only a modest reduction of ozone levels. For the $\mathrm{NO}_{\mathrm{x}}$, it has not been possible to define clear trends. However, the results reveal a limited reduction of $\mathrm{NO}_{2}$ levels and a slight increase of NO. Table 9 compares the relative impacts obtained in this study to the ones obtained by V2003. All the statistics are referring to the Strasbourg area. The results show that when alternative fuels are used in the whole region and consequently affect the composition of urban in-going plumes, the decreases of ozone levels, i.e., both peak (HMC) and background (DAC) concentrations, are enhanced. The regional contribution to the Strasbourg area mainly constitutes in low-ozone concentration air-parcels. Its effect at the local scale is to decrease the peak of ozone by 2.6 (for ETBE2) to 6.1 times (for ETBE1) and the background concentration by 5.1 (for ETBE2) to 13.7 times (for ETBE1). Anyway, this significant decrease is also related to the dramatic increase of NO. Since the ozone chemistry is controlled in this area by the depletion by NO oxidation, the credit of the important reduction of ozone levels should be given to the reaction with NO. The most interesting point of this comparison is the behavior of the VOC impact factors. The RIA and RIM are both reduced when the urban boundary conditions reflect the use of alternative fuels. However, the values obtained in this study are very small indicating that the urban levels of VOCs are only slightly affected by their regional contribution. In comparison with V2003 where the reductions of VOCs were directly related to the reduction of their emission factors, we notice that the road traffic emissions control the background regional VOC concentration levels, but have no significant impact on urban plumes. 
Table 9. Comparison between this study and V2003 of the RIM and RIA averaged over the great Strasbourg area when $100 \%$ of the fuel-GPC fleet is using the fuel blends ETBE1, ETBE2 and R2.

\begin{tabular}{lllllll}
\hline Fuel blends & \multicolumn{2}{c}{ ETBE1 } & \multicolumn{2}{c}{ ETBE2 } & \multicolumn{2}{c}{ R2 } \\
& V2003 & This study & V2003 & This study & V2003 & This study \\
\hline \multicolumn{7}{c}{ RIM } \\
\hline $\mathrm{O}_{3}$ & 0.80 & 4.87 & 1.29 & 3.30 & 0.75 & 2.75 \\
$\mathrm{NO}$ & -0.65 & -11.58 & -2.73 & -9.44 & -0.53 & -6.66 \\
$\mathrm{NO}_{2}$ & 0.57 & -6.87 & -0.84 & -5.78 & 0.58 & -3.61 \\
$\mathrm{VOC}$ & 4.98 & 0.36 & 7.21 & -3.51 & 4.38 & -0.16 \\
\hline & & & RIA & & & \\
\hline $\mathrm{O}_{3}$ & 0.45 & 6.17 & 0.91 & 4.64 & 0.42 & 3.57 \\
$\mathrm{NO}$ & -0.78 & -12.79 & -2.76 & -10.27 & -0.64 & -7.14 \\
$\mathrm{NO}$ & 0.23 & -5.62 & -1.15 & -4.67 & 0.25 & -2.92 \\
$\mathrm{VOC}$ & 3.09 & 1.1 & 4.53 & -2.10 & 2.73 & 0.63 \\
\hline
\end{tabular}

\section{Concluding remarks}

The effect of using oxygenated and reformulated fuel blends on the regional air quality has been studied by developing emission scenarios and through air quality modeling. Three fuel blends i.e., a reformulated fuel (R2), an oxygenated fuel blend (ETBE1) and a reformulated and oxygenated fuel blend (ETBE2), are used to formulate nine emission scenarios.

The results show a great improvement in the VOC levels and in particular on moderately and highly reactive alkanes, aromatics, ketones and PAN for all the fuels. These effects result directly from the modification of the fuel composition and the reduction of highly reactive compounds. Some VOC trends such as the ones of alkenes and aldehydes show a dependence on the type of fuels used. For those, it seems that the oxygenated fuel blend (ETBE1) is the most appropriate fuel to be used to reduce their levels. Using both reformulation and oxygenation (ETBE2) gives poorer results than using only reformulation (R2).

This study allowed us to show a significant increase of $\mathrm{NO}_{\mathrm{x}}$ levels at the regional scale whereas, at the local scale, the trend for $\mathrm{NO}$ is a moderate increase of concentrations and the positive impacts on $\mathrm{NO}_{2}$ in the urban centre were balanced by the negative impacts in the surrounding areas. Even if all the fuels give similar results averaged over the region with low increases, i.e., between 1 and 5\% of both the concentration peaks and daily averaged concentrations, these increases are far more important in urban areas and urban plumes (even more than $20 \%$ ).

The simulated ozone levels in all the scenarios are slightly lowered with a decrease averaged over the whole domain of 1 to $2 \%$ for both the ozone HMC and DAC. More important reductions can be noticed in urban areas (greater than $15 \%$ ) where V2003 report only a slight decrease of ozone. The sensitivity analysis revealed that the impact of alterna- tive fuels on lowering the ozone levels is not only related to the reduction of the emissions, but also to the modification of the reactivity of the VOCs.

In addition, by analysis the ozone chemistry using VOCoxidation and $\mathrm{NO}_{\mathrm{x}}$-oxidation pathways, we found different driving pathways according to the spatial distribution of the emissions. In urban areas, the ozone formation is primarily controlled by the $\mathrm{NO}_{\mathrm{x}}$-oxidation pathway. In these highly $\mathrm{NO}_{\mathrm{x}}$ concentration areas, the increase of $\mathrm{NO}_{\mathrm{x}}$ emissions from road traffic have a direct impact on the ozone levels and result in reduced concentration levels. In urban plume over rural areas, the reduction of less reactive VOCs result in less NO oxidized via the HO radical chain reactions. Thus, even if the NO levels are lower than in urban areas, the ozone can react with $\mathrm{NO}$ to give $\mathrm{NO}_{2}$. Finally, the VOC-oxidation pathway is controlling the air quality over rural areas and road traffic emission changes have only a small impact on ozone concentration levels.

By comparing with V2003 over the Strasbourg area, it is possible to estimate the effect of the contribution of the regional range transport to the urban air quality of Strasbourg and, in particular, how the use of alternative fuels at regional scale affects the local scale of Strasbourg. The results show that the urban ozone levels are greatly decreased by using alternative fuels at regional scales whereas important increases in $\mathrm{NO}_{\mathrm{x}}$ levels are reported. We found that the regional contribution to VOC urban levels was counteracting the direct effect of the reduction of VOC emissions at local scale. The use of alternative fuels leads to no improvements on the urban VOC levels or even some concentration increases in the surrounding of the city center. Using such fuels at regional scale in addition to measures taken at the urban scale allow a great improvement of the urban air quality in terms of ozone pollution. However, the urban levels of VOCs are not affected and the $\mathrm{NO}_{\mathrm{x}}$ levels are increased. 
Acknowledgements. J.-F. Vinuesa was supported by the ADEME and the CNRS through the program AGRIculture pour le Chimie et l'Energie (ECODEV/AGRICE-CNRS). The authors are grateful to the ASPA, which kindly provided the data from its measurement network.

Edited by: W. T. Sturges

\section{References}

Adrian, G. and Fiedler, F.: Simulation of unstationary wind and temperature fields over complex terrain and comparison with observations, Beitr. Phys. Atmosph., 64, 27-48, 1991.

Atkinson, R.: Gas-phase tropospheric chemistry of organic compounds, Journal of physical and chemical reference data, Monograph No. 2, 1-216, 1994.

Chock, D. P., Winkler, S. L., Chang, T. Y., Rudy, S. J., and Shen, Z. K.: Urban ozone air quality impact of emissions from vehicles using reformulated gasolines and M85, Atmos. Env., 28, 27772787, 1994.

Derwent, R. G., Jenkin, M. E., Saunders, S. M., and Pilling, M. J.: Photochemical ozone creation potentials for organic compounds in northwest Europe calculated with a master chemical mechanism, Atmos. Env., 32, 2429-2441, 1998.

Derwent, R. G., Jenkin, M. E., Saunders, S. M., Pilling, M. J., Simmonds, P. G., Passant, N. R., Dollard, G. J., Dumitrean, P., and Kent, A.: Photochemical ozone formation in north west Europe and its control, Atmos. Env., 37, 1983-1991, 2003.

Gaffney, J. S. and Marley, N. A.: Alternative Fuels, in: Air Pollution Reviews: Volume 1. The Urban Air Atmosphere and Its Effects, edite by: Brimblecombe, P. and Maynard, R., Imperial College Press, London, UK, Chapter 6, pp. 195-246, 2000.

He, B.-Q., Wang, J.-X., Hao, J.-M., Yan, X.-G., and Xiao, J.-H.: A study on emission characteristics of an EFI engine with ethanol blended gasoline fuels, Atmos. Env., 37, 949-957, 2003.

Hsieh, W.-D., Chen, R.-H., Wu, T.-L., and Lin, T.-H.: Engine performance and pollutant emission of an SI engine using ethanolgasoline blended fuels, Atmos. Env., 36, 403-410, 2002.

INTERREG II: Analyse transfrontalière de la qualité de l'air dans le Rhin supérieur - Grenzübergreifende Luftqualitätsanalyse am Oberrhein", Communauté de travail - Arbeitgemeinschaft ASPA (Association pour la Surveillance et l'étude de la pollution atmosphérique en Alsace) UMEG (Gesellschaft für Umweltmessungen und Umwelterhebungen $\mathrm{mbH}$ ), Official document, edited by: Holler, H. W. und Verlag GmbH, Killisfeldstrasse 45, D-76227 Karlsruhe (Germany), 2000.

Kirchner, F., Thuener, L. P., Barnes, L., Becker, K. H., Donner, B., and Zabel, F.: Thermal lifetimes of peroxynitrates occuring in the atmospheric degradation of oxygenated fuels additives, Env. Sci. Tech., 31, 1801-1804, 1997.

Kivi, J., Niemi, A., Nylund, N., Kuto, M., and Orre, K.: Use of MTBE and ETBE as gasoline reformulation components, SAE Technical Paper 922379, 1992.

Kumini, H., Ishizawa, S., and Yoshikawa, Y.: Three-dimensional air quality simulation study on low-emission vehicles in the southern California, Atmos. Env., 31, 145-158, 1997.

Lopez de Rodas, B., and Marduel, J.-L.: Influence sur la nature et le niveau des émissions à l'échappement, d'une incorpora- tion de composés oxygénés dans les essences, PV no. 97/00581, U.T.A.C., BP212, 91311 Montlhery, France, 1997.

Marthur, R. and Peters, L. K.: Sub-grid representation of emission source clusters in regional air quality modeling, Atmos. Env., 26, 3219-3238, 1992.

McDonald, C., Shore, P., Lee, G., Otter, G. D., and Humphries, D.: The effect of gasoline composition on stochiometry and exhaust emissions, SAE Technical Paper 941868, 1994.

Moussiopoulos, N.: The EUMAC zooming model, a tool for localto-regional air quality studies, Meteorolog. Atmos. Phys., 57, 115-133, 1995.

Noorman, M.: The effect of MTBE, DIPE and TAME on vehicle emissions, SAE Technical Paper 932668, 1993.

Ponche, J.-L., Schneider, C., and Mirabel, Ph.: Methodology and results of the REKLIP atmospheric emission inventory of the upper Rhine valley transborder region, Wat. Air Soil Pollut., 124, 61-93, 2000.

Ponche, J.-L. and Vinuesa, J.-F.: Emission scenarios for air quality management and applications at local and regional scales including the effects of the future European emission regulation (2015) for the upper Rhine valley, Atmos. Chem. Phys., 5, 999-1014, 2005, mboxhttp://www.atmos-chem-phys.net/5/999/2005/.

REKLIP: Atlas climatique du fossé Rhénan méridional, 1 volume texte et 2 volumes cartes, Ed. COPRUR, F-67000 Strasbourg, 1995, ISBN 2-903297-097-5, 1995.

REKLIP: Qualité de l'Air et Climat Régional/LuftQualität und Regionalklima, Rapport final, volume 3/Schlussbericht Band 3, Ed. COPRUR F-67000 Strasbourg, 1999, ISBN 2-84208-035-1, 1999.

Reuter, R., Benson, J., Burns, V., Gorse, R., Hochhausser, A., Koelh, W., Painter, L., Rippon, B., and Rutherford, J.: Effects of oxygenated fuels and RVP on automotive emission auto-oil improvement program, SAE Technical Paper 920326, 1992.

Schneider, Ch., Kessler, Ch., and Moussiopoulos, N.: Influence of emission input data on ozone level predictions for the Upper Rhine valley, Atmos. Environ., 31, 3187-3205, 1997.

Sillman, S., Logan, J. A., and Wofsy, S. C.: The sensitivity of ozone to nitrogen oxides and hydrocarbons in regional ozone episodes, J. Geophys. Res., 95, 1837-1851, 1990.

Smith, D. F., Kleindienst, T. E., Hudgens, E. E., and McIver, C. D.: Kinetics and mechanism of the atmospheric oxidation of ethyl tertiary butyl ether, Int. J. Chem. Kin., 24, 199-215, 1992.

Stockwell, W., Kirchner, F., and Kuhn, M.: A new mechanism for regional atmospheric chemistry modelling, J. Geophys. Res., 102, 3789-3812, 1997.

Vinuesa, J.-F.: Modélisation de la qualité de l'air: Impact à l'échelle locale et régionale de l'utilisation de carburants automobiles modifiés, PhD thesis, L. Pasteur University of Strasbourg I, 2000.

Vinuesa, J.-F., Hyacinthe, C., Fayet, S., Perron, G., Kleinpeter, J., Target, A., Mirabel, Ph., and Ponche, J.-L.: Upper Rhine valley air quality modeling for the 9-15th May 1998 episode and future abatement strategies, in: EUROTRAC-2 Symposium 2000, Springler-Verlag, Berlin Heidelberg, 2001.

Vinuesa, J.-F., Mirabel, Ph., and Ponche J.-L.: Air quality effects of using reformulated and oxygenated gasoline fuel blends: Application to the Strasbourg area (F), Atmos. Environ., 37, 1757$1774,2003$. 